\title{
PROTOTIPE SISTEM KONTROL LAMPU LED MELALUI JARINGAN INTERNET BERBASIS ARDUINO
}

\author{
Anenda Happy Safitra \\ Departemen Teknik Elektro dan Informatika, Sekolah Vokasi, Universitas Gadjah Mada \\ E-mail: anenda.happy.s@mail.ugm.ac.id
}

\begin{abstract}
Digital technology has been evolving significantly nowdays. It induces the emerging of many smart-based technology inovations. One of the emerging digital technology is Internet of Things (IoT) of which one of its implementation is smart home system. Basically, the one of the concept of smart home is enabling user to control and monitor electronics devices in order to minimize wasted energy from user's neglectance to switching off the lights. Towards the aim, the author conducted research on the energy efficiency of lamps used in Internet of Things (IoT) technology.The research developed a controlling system (on-off) of 5 arduino-based LED lamps. The website would control the LED lamps which will send data to the server where the server will continue the data to arduino to read the command: $\mathrm{ON}$ or OFF. Next, arduino will send the LED's status to the server to perform the LED status display on the website. Blackbox testing was used to evaluate the performance of hardware and software built for LED lights controlling and monitoring system using a website. It can be concluded that the designed system, equipped with controlling and monitoring ability by the user, was able to reduce the energy extravagance further.
\end{abstract}

Keywords : IoT, website, LED, Blackbox testing

Intisari -Teknologi digital telah mengalami perkembangan yang sangat signifikan dewasa ini. Perkembangan ini memicu munculnya inovasi - inovasi berbasis teknologi cerdas. Salah satu teknologi digital tersebut adalah Internet of Things (IoT) dengan salah satu produk terapannya adalah rumah cerdas (smart home). Konsep dari rumah cerdas adalah adanya kemampuan pengguna mengendalikan dan memantau piranti elektronik rumahan agar meminimalisir pemborosan energi listrik akibat dari kelalaian mematikan piranti elektronik tersebut. Dengan tujuan tersebut, penulis melakukan penelitian terhadap efisiensi energi lampu yang digunakan pada teknologi Internet of Things (IoT). Penelitian ini mengembangkan sistem pengendalian (on-off) 5 buah lampu LED berbasis arduino. Website akan melakukan kendali lampu LED yang akan mengirimkan sebuah data ke server kemudian server akan melanjutkan data tersebut ke arduino untuk melakukan pembacaan perintah yaitu ON atau OFF. Selanjutnya arduino akan mengirimkan status LED ke server untuk melakukan penampilan status LED pada website. Blackbox testing digunakan untuk menguji kinerja piranti keras dan lunak yang membentuk sistem pengendali lampu LED menggunakan tampilan website. Melalui pengujian ini, dapat disimpulkan bahwa sistem yang dirancang dengan kemampuan pengendalian dan pemantauan oleh pengguna, mampu mengurangi pemborosan energi.

Kata kunci : IoT, website, LED, Blackbox testing

\section{PENDAHULUAN}

Kehidupan modern saat ini menuntut mobilitas yang semakin tinggi, segala sesuatu dirancang untuk mempermudah kehidupan manusia. Teknologi tidak luput menjadi salah satu masalah utama yang dikembangkan pada modern ini. Hal ini dapat dilihat dari perkembanngan jaringan internet yang telah mengalami kemajuan pesat pada satu dekade terakhir. Internet saat ini tidak hanya digunakan untuk mengakses email juga hiburan - hiburan lainnya namun bisa digunakan sebagai sarana pengontrol elektronik jarak jauh baik di kantor maupun di rumah, yang biasa dikenal sebagai smart home.

Rumah Cerdas (smart home) adalah sistem berbasis teknologi informasi dan komunikasi yang terdiri dari piranti keras dan lunak yang secara otomatis mengendalikan kerja dari piranti - piranti elektronis yang ada di dalam tempat tinggal. Tujuan dari sistem ini adalah meningkatkan kualitas hidup sehari - hari dalam hal kenyamanan, keamanan, dan penghematan energi. Prinsip kerja kendali otomatis ini juga dilengkapi dengan kemampuan pengawasan (monitoring) kondisi - kondisi piranti elektronik tersebut. Dengan kemajuan teknologi piranti bergerak (mobile device), piranti lunak dalam bentuk aplikasi bergerak (mobile application) memungkinkan proses pada teknologi Rumah Cerdas tertanam dalam gadget atau mobile phone pengguna.
Lampu merupakan alat penerang pada tempat yang gelap atau pada malam hari, lampu sangat dibutuhkan oleh masyarakat sehingga sering kali tejadi kelalaian dalam mengendalikan lampu. Seringkali lampu masih menyala pada siang hari atau pada tempat yang terang, disebabkan karena pengguna lupa mematikan.

Pada penelitian ini menggunakan Website sebagai media untuk antarmuka kontrol piranti elektronis rumah tangga dan dibuatlah "Prototipe Sistem Kontrol Lampu LED melalui internet Berbasis Arduino". Sistem ini diajukan sebagai upaya untuk menghemat pengunaan energi listrik sekaligus memampukan pengguna mengendalikan dan memantau operasional dari piranti elektronik rumahan.

\section{METODE}

\subsection{Diagram Blok Sistem}

Dalam sistem ini, user melalukan pengendalian lampu LED melalui web, kemudian web melakukan publish status LED melalui protokol MQTT dan Arduino akan mensubscribe status LED tersebut, Arduino melakukan pengubah LED akan nyala atau padam sesuai dengan perintah dari status yang didapat. Selanjutnya arduino akan mem-publish status LED melalui protokol MQTT yang selanjutnya akan diterima webserver untuk melakukan penampilan status LED menyala atau padam pada halaman kontrol website yang mana keseluruhan diproses pada Alibaba Cloud Computing sebagai server. Blok diagram dirancang untuk mempermudah dalam perancangan 
instalasi alat. Hal ini digunakan untuk menunjukkan alur kerja dari sistem yang dirancang, seperti pada Gambar 1.
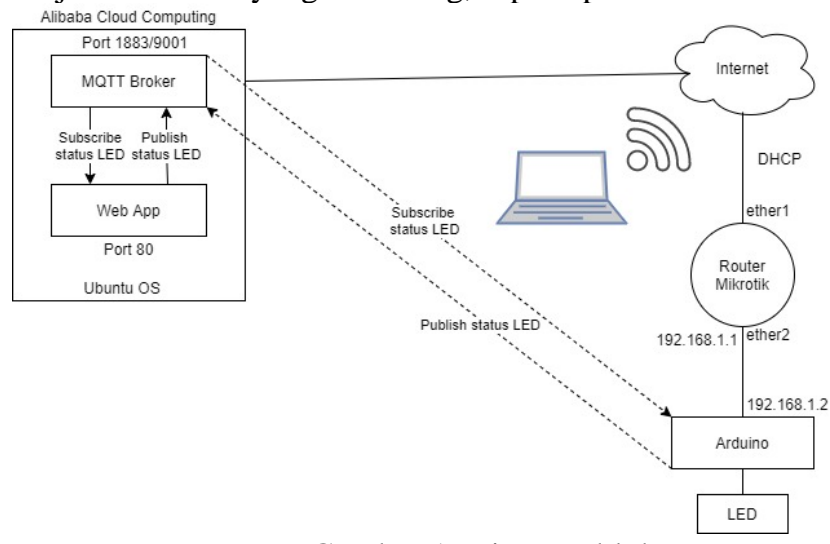

Gambar 1. Diagram blok

\subsection{Perancangan Alat}

Rangkaian yang dirancang berpusat pada arduino yang berperan sebagai pusat kontrol sistem. Arduino diberi tambahan modul ethernet shield agar dapat berkomunikasi melewati router. Bagian-bagian lain yang dihubungkan ke perangkat arduino adalah LED, resistor, jumper dan breadboard yang dapat dilihat rancangannya seperti Gambar 2.

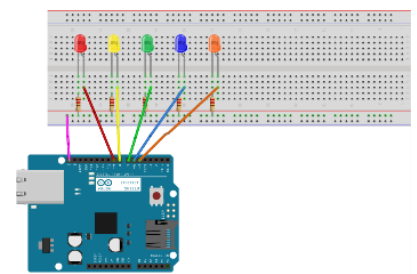

Gambar 2. Perancangan Alat

\subsection{Diagram Jaringan}

Pada Gambar 3. diagram jaringan sebagai rujukan dalam menjelaskan cara berbagi koneksi internet. Interface yang digunakan adalah wlanl dan ether2. Wlanl adalah interface dengan tipe wireless yang berfungsi sebagai sebuah wireless adapter dan menerima koneksi internet dari SSID "LOGIC SOLUTION 3". Ethernet shield adalah perangkat yang akan menerima koneksi internet melalui ether2.

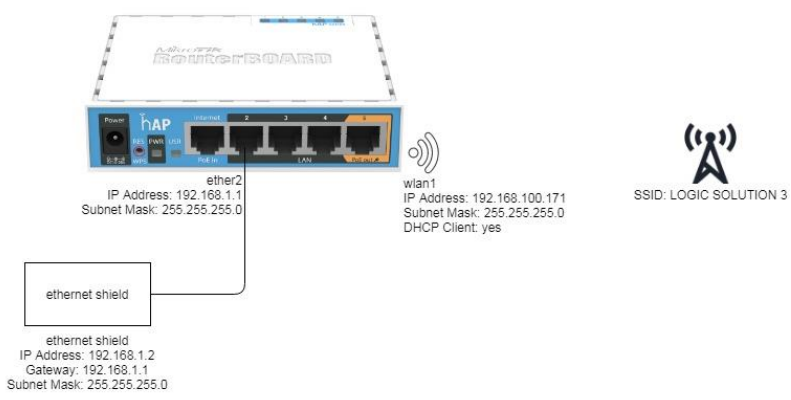

Gambar 3. Diagram Jaringan

\subsection{Komunikasi Web dengan Mikrokontroler}

Diagram komunikasi antara web dengan mikrokontroler pada gambar 4. bukan berupa komunikasi langsung, melainkan membutuhkan pihak ketiga berupa MQTT broker. Terdapat dua jalur komunikasi yang dilakukan yaitu setiap perintah yang masuk dari web akan dikirim ke
MQTT broker lalu dari MQTT broker akan diteruskan ke mikrokontroler dan status yang di olah Arduino dari lampu LED yang akan digunakan sebagai feedback dikirimkan ke MQTT broker yang kemudian diteruskan ke web.

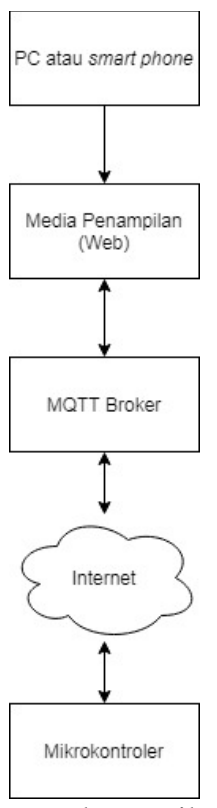

Gambar 4. Diagram komunikasi web dengan mikrokontroler

\subsection{Activity Diagram}

Diagram ini digunakan untuk menggambarkan mengenai garis besar bagaimana urutan sistem akan bekerja. Pada sistem yang dirancang ini terdapat 3 komponen utama sistem yaitu web browser, webserver dan MQTT Broker, mikrokontroler. Ilustrasi tersebut digambarkan seperti yang tampak pada Gambar 5.

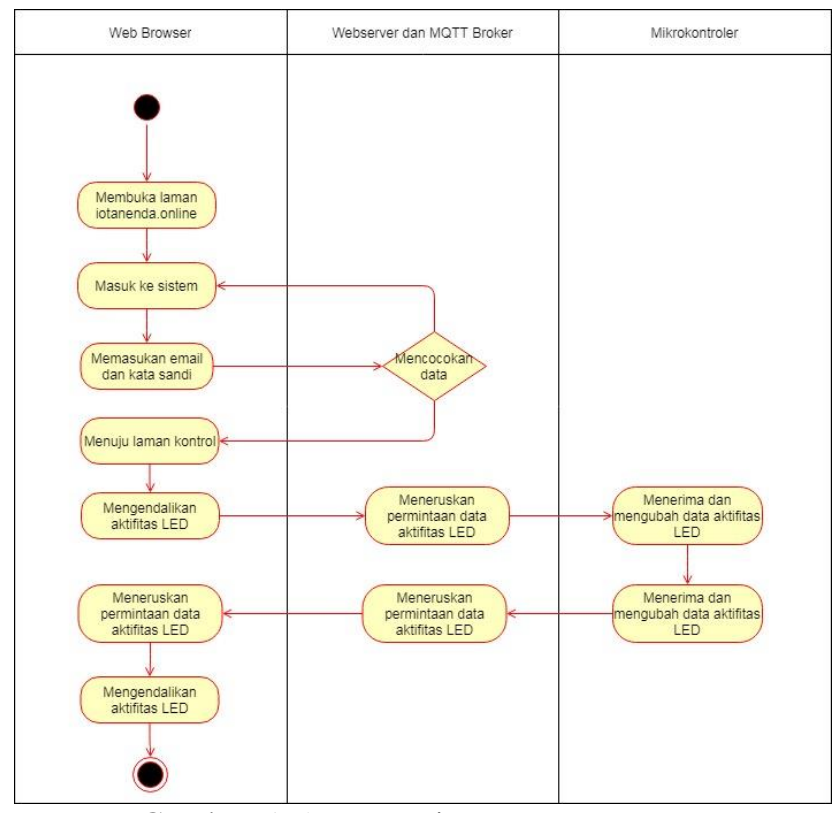

Gambar 5. Activity Diagram

\subsection{Mockup Tampilan Website}

Saat pengguna pertama kali masuk ke laman website, maka pengguna harus memasukan email dan password. Maka dari itulah diperlukan laman Login yang berfungsi untuk memberikan otentikasi dan otorisasi pada pengguna 
yang berhak untuk masuk ke dalam sistem yang dirancang. Tampilan dari laman ini dapat dilihat pada Gambar 6.

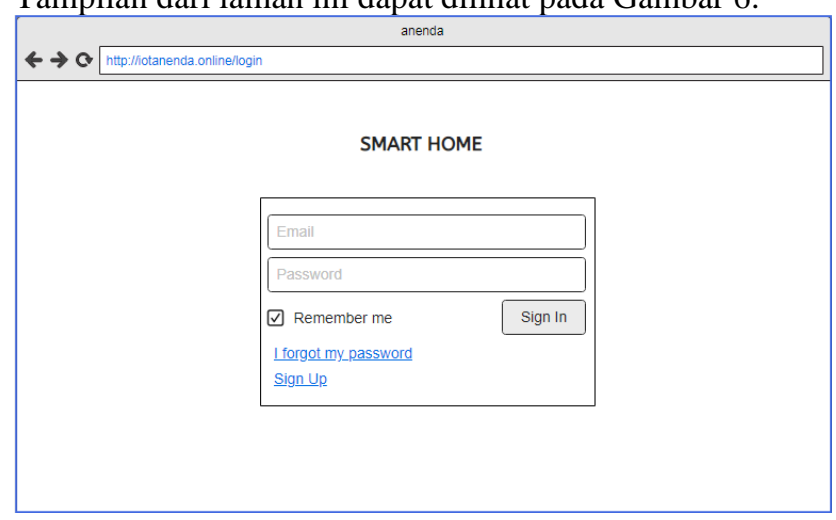

Gambar 6. Mockup Tampilan Login

Menu ini terdapat tombol $O N / O F F$ pada setiap lampu dan terdapat status terkini mengenai lampu LED nyala atau mati. Tampilan dari laman ini dapat dilihat pada Gambar 7.

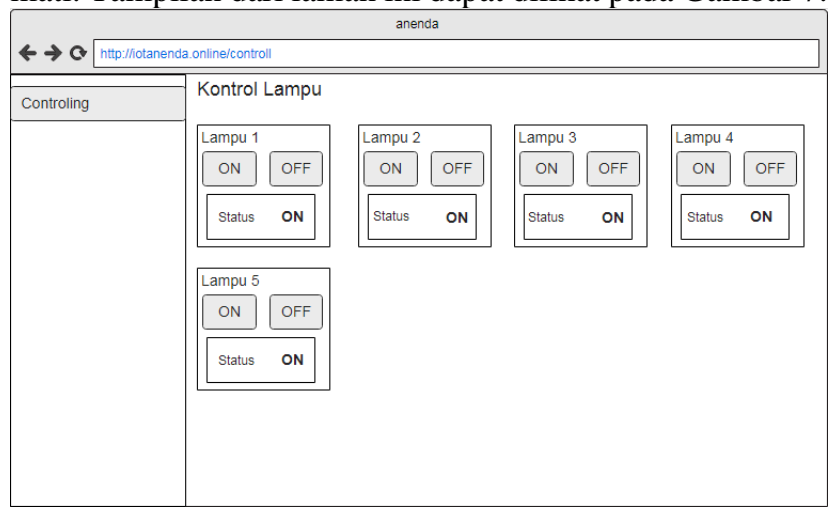

Gambar 7. Mockup Tampilan Kontrol

\section{HASIL DAN PEMBAHASAN}

Pada Gambar 8. mikrokontoler terhubung ke router mikrotik untuk dapat tersambung dengan internet. Dengan melakukan pengendalian pada website maka lampu LED akan menyala atau mati. Selanjutnya arduino akan mengirim data sesuai dengan kondisi status LED. Seluruh kondisi status LED yang berjalan pada mikrokontroler akan ditampilkan pada website.

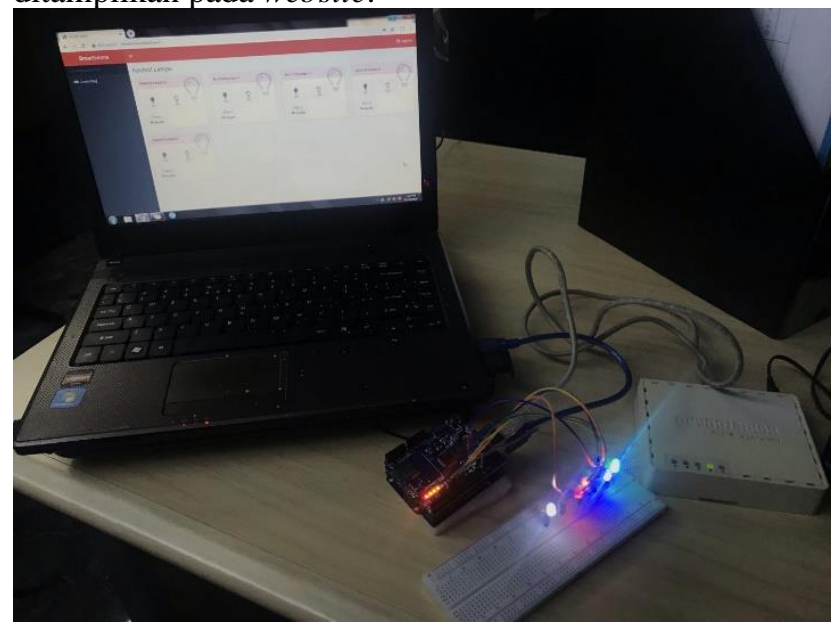

Gambar 8. Prototipe sistem kontrol lampu LED melalui internet berbasis arduino
Pada pengujian ini, LED yang dihubungkan menggunakan jumper dan diproses oleh mikrokontroler. Adapun skenario dan hasil dari pengujian LED dengan metode blackbox testing sesuai dengan kebutuhan sistem disajikan dalam bentuk Tabel 1 .

Tabel 1. Blackbox testing Pada LED

\begin{tabular}{|l|l|l|l|}
\hline \multicolumn{1}{|c|}{$\begin{array}{c}\text { Butir } \\
\text { Uji }\end{array}$} & \multicolumn{1}{|c|}{$\begin{array}{c}\text { Hasil yang } \\
\text { Diharapkan }\end{array}$} & $\begin{array}{c}\text { Hasil } \\
\text { Sebenarn } \\
\text { ya }\end{array}$ & $\begin{array}{c}\text { Kesimpula } \\
\mathbf{n}\end{array}$ \\
\hline $\begin{array}{l}\text { Status } \\
\text { ON }\end{array}$ & $\begin{array}{l}\text { LED dapat menyala } \\
\text { ketika diberikan } \\
\text { tegangan }(H I G H) .\end{array}$ & $\begin{array}{l}\text { LED } \\
\text { menyala }\end{array}$ & $\square$ Berhasil \\
\hline $\begin{array}{l}\text { Status } \\
\text { OFF }\end{array}$ & $\begin{array}{l}\text { LED dapat padam } \\
\text { ketika tidak ada } \\
\text { tegangan }(L O W) .\end{array}$ & $\begin{array}{l}\text { LED } \\
\text { padam }\end{array}$ & $\square$ Berhasil \\
& \multicolumn{3}{|c}{} \\
\hline
\end{tabular}

\subsection{Pengujian Ethernet Shield}

Pada pengujian ini, Ethernet shield akan langsung dihubungkan dengan mikrokontroler dan mikrotik untuk dapat terhubung dengan internet. Adapun skenario dan hasil dari pengujian Ethernet shield dengan metode blackbox testing menurut kebutuhan sistem disajikan dalam bentuk Tabel 2 .

\section{Tabel 2. Blackbox testing Pada Ethernet shield}

\begin{tabular}{|c|c|c|c|}
\hline Butir Uji & $\begin{array}{c}\text { Hasil yang } \\
\text { Diharapka } \\
n\end{array}$ & $\begin{array}{c}\text { Hasil } \\
\text { Sebenarnya }\end{array}$ & $\begin{array}{c}\text { Kesimpul } \\
\text { an }\end{array}$ \\
\hline $\begin{array}{l}\text { Terhubung } \\
\text { ke internet }\end{array}$ & $\begin{array}{l}\text { Ethernet } \\
\text { shield } \\
\text { terkoneksi } \\
\text { dengan } \\
\text { internet. }\end{array}$ & $\begin{array}{l}\text { Ethernet shield } \\
\text { terhubung ke } \\
\text { internet, dapat } \\
\text { membuka } \\
\text { website dan } \\
\text { menampilkan } \\
\text { data. }\end{array}$ & $\begin{array}{l}\nabla \\
\text { Berhasil } \\
\square \text { Gagal }\end{array}$ \\
\hline
\end{tabular}

\subsection{Pengujian Router Mikrotik}

Pada pengujian ini, Router Mikrotik akan langsung dihubungkan dengan Ethernet Shield melalui Ether2 dan internet melalui wlan1. Adapun scenario dan hasil dari pengujian Router Mikrotik dengan metode blackbox testing sesuai kebutuhan sistem disajikan oleh Tabel 3.

Tabel 3. Blackbox testing Pada Router Mikrotik

\begin{tabular}{|c|l|l|l|}
\hline Butir Uji & $\begin{array}{l}\text { Hasil yang } \\
\text { Diharapkan }\end{array}$ & $\begin{array}{c}\text { Hasil } \\
\text { Sebenarnya }\end{array}$ & $\begin{array}{c}\text { Kesimpula } \\
\text { n }\end{array}$ \\
\hline $\begin{array}{l}\text { Terhubung } \\
\text { ke internet }\end{array}$ & $\begin{array}{l}\text { Router } \\
\text { Mikrotik } \\
\text { dapat melalui } \\
\text { wlan1 }\end{array}$ & $\begin{array}{l}\text { Router } \\
\text { Mikrotik } \\
\text { terkoneksi } \\
\text { dengan }\end{array}$ & $\square$ Berhasil \\
& terkoneksi & $\begin{array}{l}\text { internet } \\
\text { sehingal } \\
\text { dengan }\end{array}$ & \\
& internet. & ke ip google & \\
& & king & \\
\hline
\end{tabular}

\subsection{Pengujian LED}




\begin{tabular}{|c|c|c|c|}
\hline $\begin{array}{l}\text { Terhubung } \\
\text { ke Ethernet } \\
\text { shield }\end{array}$ & $\begin{array}{l}\text { Router } \\
\text { Mikrotik } \\
\text { dapat melalui } \\
\text { Ether2 } \\
\text { terkoneksi } \\
\text { dengan } \\
\text { Ethernet } \\
\text { shield. }\end{array}$ & $\begin{array}{l}\text { Router } \\
\text { Mikrotik } \\
\text { terkoneksi } \\
\text { dengan } \\
\text { Ethernet } \\
\text { shield } \\
\text { sehingga } \\
\text { dapat ping } \\
\text { ke ip ethenet } \\
\text { shield }\end{array}$ & $\begin{array}{l}\square \text { Berhasil } \\
\square \text { Gagal }\end{array}$ \\
\hline
\end{tabular}

\subsection{Pengujian Menu Login}

Pengujian pada laman ini bertujuan untuk mengetahui apakah laman login dapat berjalan sesuai skenario dan apakah sudah memenuhi kebutuhan yang diharapkan. Tahap pertama, user masuk ke laman login menggunakan email dan password yang sudah terdaftar pada database. Hasilnya menyatakan bahwa user dapat masuk dengan email dan password yang sudah terdaftar. Kondisi selanjutnya yang diuji oleh user ialah mengenai peringatan apabila mengisi password saja. Maka hasil dari percobaan menyatakan user gagal untuk masuk dan mendapatkan peringatan untuk mengisi email. Pengujian tersebut juga dicoba apabila hanya mengisi email saja. Beberapa butir uji dibawah ini akan menjabarkan mengenai menu login dengan metode blackbox testing yang ditunjuk pada Tabel 4.

Tabel 4. Blackbox Testing menu Login

\begin{tabular}{|c|c|c|c|}
\hline Butir Uji & $\begin{array}{c}\text { Hasil yang } \\
\text { Diharapkan }\end{array}$ & $\begin{array}{c}\text { Hasil } \\
\text { Sebenarnya }\end{array}$ & $\underset{n}{\text { Kesimpula }}$ \\
\hline $\begin{array}{l}\text { Memasukkan } \\
\text { username dan } \\
\text { password } \\
\text { yang tidak } \\
\text { terdaftar }\end{array}$ & $\begin{array}{l}\text { Sistem } \\
\text { memberitahu } \\
\text { bahwa } \\
\text { kombinasi } \\
\text { salah }\end{array}$ & $\begin{array}{l}\text { Muncul } \\
\text { notifikasi } \\
\text { "These } \\
\text { credentials do } \\
\text { not match our } \\
\text { records." }\end{array}$ & $\begin{array}{l}\square \text { Berhasil } \\
\square \text { Gagal }\end{array}$ \\
\hline $\begin{array}{l}\text { Memasukkan } \\
\text { email saja }\end{array}$ & $\begin{array}{l}\text { Terdapat } \\
\text { peringatan } \\
\text { untuk } \\
\text { memasukkan } \\
\text { password }\end{array}$ & $\begin{array}{l}\text { Terdapat } \\
\text { peringatan di } \\
\text { bawah kolom } \\
\text { password } \\
\text { "The } \\
\text { password field } \\
\text { is required." }\end{array}$ & $\begin{array}{l}\square \text { Berhasil } \\
\square \text { Gagal }\end{array}$ \\
\hline $\begin{array}{l}\text { Memasukkan } \\
\text { password saja }\end{array}$ & $\begin{array}{l}\text { Terdapat } \\
\text { peringatan } \\
\text { untuk } \\
\text { memasukkan } \\
\text { email }\end{array}$ & $\begin{array}{l}\text { Terdapat } \\
\text { peringatan di } \\
\text { bawah kolom } \\
\text { email "The } \\
\text { email field is } \\
\text { required." }\end{array}$ & $\begin{array}{l}\square \text { Berhasil } \\
\square \text { Gagal }\end{array}$ \\
\hline $\begin{array}{l}\text { Memasukkan } \\
\text { email dengan } \\
\text { benar namun } \\
\text { password } \\
\text { salah }\end{array}$ & $\begin{array}{l}\text { Sistem } \\
\text { memberitahu } \\
\text { bahwa } \\
\text { kombinasi } \\
\text { salah }\end{array}$ & $\begin{array}{l}\text { Muncul } \\
\text { notifikasi } \\
\text { "These } \\
\text { credentials do } \\
\text { not match our } \\
\text { records." }\end{array}$ & $\begin{array}{l}\square \text { Berhasil } \\
\square \text { Gagal }\end{array}$ \\
\hline $\begin{array}{l}\text { Memasukkan } \\
\text { password } \\
\text { dengan benar }\end{array}$ & $\begin{array}{l}\text { Sistem } \\
\text { memberitahu } \\
\text { bahwa }\end{array}$ & $\begin{array}{l}\text { Muncul } \\
\text { notifikasi } \\
\text { "These } \\
\text { credentials do }\end{array}$ & $\begin{array}{l}\square \text { Berhasil } \\
\square \text { Gagal }\end{array}$ \\
\hline
\end{tabular}

\begin{tabular}{|l|l|l|l|}
\hline $\begin{array}{l}\text { namun email } \\
\text { salah }\end{array}$ & $\begin{array}{l}\text { kombinasi } \\
\text { salah }\end{array}$ & $\begin{array}{l}\text { not match our } \\
\text { records.” }\end{array}$ & \\
\hline $\begin{array}{l}\text { Memasukkan } \\
\text { email dan } \\
\text { password } \\
\text { dengan benar }\end{array}$ & $\begin{array}{l}\text { Dapat masuk } \\
\text { ke sistem dan } \\
\text { menampilkan } \\
\text { menu kontrol }\end{array}$ & $\begin{array}{l}\text { Berhasil } \\
\text { masuk ke } \\
\text { sistem dan } \\
\text { menampilkan } \\
\text { menu kontrol }\end{array}$ & $\square$ Gagal \\
\hline
\end{tabular}

\subsection{Pengujian Menu Kontrol}

Pada menu kontrol terdapat button on/off untuk mengendali pada masing-masing LED. User melalukan pengujian untuk menu ini terutama untuk bagian pengendalian lampu LED sebagai salah satu poin utama dari penelitian ini yaitu on/off lampu LED. Hasil dari percobaan user menyata bahwa dapat melakukan pengendalian lampu pada setiap lampu LED dan dapat melihat hasil status dari pengendalian lampu LED tersebut. Beberapa butir uji dibawah ini akan menjabarkan mengenai menu kontrol dengan metode blackbox testing yang ditunjuk pada Tabel 5 .

Tabel 5. Blackbox Testing menu Kontrol

\begin{tabular}{|c|c|c|c|}
\hline Butir Uji & $\begin{array}{l}\text { Hasil yang } \\
\text { Diharapkan }\end{array}$ & $\begin{array}{c}\text { Hasil } \\
\text { Sebenarnya }\end{array}$ & $\begin{array}{c}\text { Kesimpula } \\
\text { n }\end{array}$ \\
\hline $\begin{array}{l}\text { Menghidup } \\
\text { kan LED } 1\end{array}$ & $\begin{array}{l}\text { Mengklik } \\
\text { button "ON" } \\
\text { untuk } \\
\text { menyalakan } \\
\text { LED 1 }\end{array}$ & $\begin{array}{l}\text { Dapat } \\
\text { mengklik } \\
\text { button " } O N " \\
\text { dan LED } 1 \\
\text { menyala }\end{array}$ & $\begin{array}{l}\square \text { Berhasil } \\
\square \text { Gagal }\end{array}$ \\
\hline $\begin{array}{l}\text { Mematikan } \\
\text { LED } 1\end{array}$ & $\begin{array}{l}\text { Mengklik } \\
\text { button "OFF" } \\
\text { untuk } \\
\text { menyalakan } \\
\text { LED 1 }\end{array}$ & $\begin{array}{lr}\begin{array}{l}\text { Dapat } \\
\text { mengklik }\end{array} \\
\text { button } \\
\text { "OFF" dan } \\
\text { LED } \\
\text { padam }\end{array}$ & $\begin{array}{l}\square \text { Berhasil } \\
\square \text { Gagal }\end{array}$ \\
\hline $\begin{array}{l}\text { Status } \\
\text { Lampu } 1\end{array}$ & $\begin{array}{l}\text { Menampilkan } \\
\text { status Lampu } \\
1\end{array}$ & $\begin{array}{l}\text { Dapat } \\
\text { melihat } \\
\text { status LED } 1 \\
\text { "nyala" atau } \\
\text { "padam" }\end{array}$ & $\begin{array}{l}\square \text { Berhasil } \\
\square \text { Gagal }\end{array}$ \\
\hline $\begin{array}{l}\text { Menghidup } \\
\text { kan LED } 2\end{array}$ & $\begin{array}{l}\text { Mengklik } \\
\text { button "ON" } \\
\text { untuk } \\
\text { menyalakan } \\
\text { LED } 2\end{array}$ & $\begin{array}{l}\text { Dapat } \\
\text { mengklik } \\
\text { button " } O N \text { " } \\
\text { dan LED } 2 \\
\text { menyala }\end{array}$ & $\begin{array}{l}\square \text { Berhasil } \\
\square \text { Gagal }\end{array}$ \\
\hline $\begin{array}{l}\text { Mematikan } \\
\text { LED } 2\end{array}$ & $\begin{array}{l}\text { Mengklik } \\
\text { button "OFF", } \\
\text { untuk } \\
\text { menyalakan } \\
\text { LED } 2\end{array}$ & 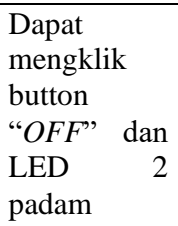 & $\begin{array}{l}\square \text { Berhasil } \\
\square \text { Gagal }\end{array}$ \\
\hline $\begin{array}{l}\text { Status } \\
\text { Lampu } 2\end{array}$ & $\begin{array}{l}\text { Menampilkan } \\
\text { status Lampu } \\
2\end{array}$ & $\begin{array}{l}\text { Dapat } \\
\text { melihat } \\
\text { status LED } 2 \\
\text { "nyala" atau } \\
\text { "padam" }\end{array}$ & $\begin{array}{l}\square \text { Berhasil } \\
\square \text { Gagal }\end{array}$ \\
\hline
\end{tabular}




\begin{tabular}{|c|c|c|c|}
\hline $\begin{array}{l}\text { Menghidup } \\
\text { kan LED } 3\end{array}$ & $\begin{array}{l}\text { Mengklik } \\
\text { button "ON" } \\
\text { untuk } \\
\text { menyalakan } \\
\text { LED } 3\end{array}$ & $\begin{array}{l}\text { Dapat } \\
\text { mengklik } \\
\text { button " } O N \text { " } \\
\text { dan LED } 3 \\
\text { menyala }\end{array}$ & $\begin{array}{l}\square \text { Berhasil } \\
\square \text { Gagal }\end{array}$ \\
\hline $\begin{array}{l}\text { Mematikan } \\
\text { LED } 3\end{array}$ & $\begin{array}{l}\text { Mengklik } \\
\text { button "OFF" } \\
\text { untuk } \\
\text { menyalakan } \\
\text { LED } 3\end{array}$ & $\begin{array}{lr}\text { Dapat } & \\
\text { mengklik } & \\
\text { button } & \\
\text { "OFF" dan } \\
\text { LED } \\
\text { padam }\end{array}$ & $\begin{array}{l}\square \text { Berhasil } \\
\square \text { Gagal }\end{array}$ \\
\hline $\begin{array}{l}\text { Status } \\
\text { Lampu } 3\end{array}$ & $\begin{array}{l}\text { Menampilkan } \\
\text { status Lampu } \\
3\end{array}$ & $\begin{array}{l}\text { Dapat } \\
\text { melihat } \\
\text { status LED } 3 \\
\text { "nyala" atau } \\
\text { "padam" }\end{array}$ & $\begin{array}{l}\square \text { Berhasil } \\
\square \text { Gagal }\end{array}$ \\
\hline $\begin{array}{l}\text { Menghidup } \\
\text { kan LED } 4\end{array}$ & $\begin{array}{l}\text { Mengklik } \\
\text { button "ON" } \\
\text { untuk } \\
\text { menyalakan } \\
\text { LED } 4\end{array}$ & $\begin{array}{l}\text { Dapat } \\
\text { mengklik } \\
\text { button " } O N " \\
\text { dan LED } 4 \\
\text { menyala }\end{array}$ & $\begin{array}{l}\square \text { Berhasil } \\
\square \text { Gagal }\end{array}$ \\
\hline $\begin{array}{l}\text { Mematikan } \\
\text { LED } 4\end{array}$ & $\begin{array}{l}\text { Mengklik } \\
\text { button "OFF" } \\
\text { untuk } \\
\text { menyalakan } \\
\text { LED } 4\end{array}$ & $\begin{array}{lr}\text { Dapat } & \\
\text { mengklik } & \\
\text { button } & \\
\text { "OFF" dan } \\
\text { LED } \\
\text { padam }\end{array}$ & $\begin{array}{l}\square \text { Berhasil } \\
\square \text { Gagal }\end{array}$ \\
\hline $\begin{array}{l}\text { Status } \\
\text { Lampu } 4\end{array}$ & $\begin{array}{l}\text { Menampilkan } \\
\text { status Lampu } \\
4\end{array}$ & $\begin{array}{l}\text { Dapat } \\
\text { melihat } \\
\text { status LED } 4 \\
\text { "nyala" atau } \\
\text { "padam" }\end{array}$ & $\begin{array}{l}\square \text { Berhasil } \\
\square \text { Gagal }\end{array}$ \\
\hline $\begin{array}{l}\text { Menghidup } \\
\text { kan LED } 5\end{array}$ & $\begin{array}{l}\text { Mengklik } \\
\text { button "ON" } \\
\text { untuk } \\
\text { menyalakan } \\
\text { LED } 5\end{array}$ & $\begin{array}{l}\text { Dapat } \\
\text { mengklik } \\
\text { button " } O N \text { " } \\
\text { dan LED } 5 \\
\text { menyala }\end{array}$ & $\begin{array}{l}\square \text { Berhasil } \\
\square \text { Gagal }\end{array}$ \\
\hline $\begin{array}{l}\text { Mematikan } \\
\text { LED } 4\end{array}$ & $\begin{array}{l}\text { Mengklik } \\
\text { button "OFF" } \\
\text { untuk } \\
\text { menyalakan } \\
\text { LED } 5\end{array}$ & $\begin{array}{l}\text { Dapat } \\
\text { mengklik } \\
\text { button } \\
\text { "OFF" dan } \\
\text { LED } \\
\text { padam }\end{array}$ & $\begin{array}{l}\square \text { Berhasil } \\
\square \text { Gagal }\end{array}$ \\
\hline $\begin{array}{l}\text { Status } \\
\text { Lampu } 5\end{array}$ & $\begin{array}{l}\text { Menampilkan } \\
\text { status Lampu } \\
5\end{array}$ & $\begin{array}{l}\text { Dapat } \\
\text { melihat } \\
\text { status LED } 5 \\
\text { "nyala" atau } \\
\text { "padam" }\end{array}$ & $\begin{array}{l}\square \text { Berhasil } \\
\square \text { Gagal }\end{array}$ \\
\hline
\end{tabular}

menunjukkan bahwa fungsi pada perangkat keras maupun website untuk memantau maupun mengendalikan lampu LED telah berjalan dengan baik. Sistem dapat bekerja dengan baik dan dapat mengirim dan menerima data ke server yakni Alibaba Cloud Computing. Sistem yang dirancang dapat digunakan untuk mempermudah pengendalian dan pemantuan status lampu LED secara daring dan jarak jauh melalui website.

\section{DAFTAR PUSTAKA}

[1] Amir, A., \& Faisal, N. (2015). Perancangan dan Penerapan Sistem Kontrol Peralatan Elektronik Jarak Jauh Berbasis Web. Jurnal Mekanikal, Vol. 6 No. 2.

[2] Arduino - Product [WWW Document]. (n.d.). Retrieved Februari 15, 2019, from http://www.arduino.cc/en/Main/Products

[3] Fajar, T. (2009). Perancangan Software Aplikasi Pervasive Smart Home. Seminar Nasional Aplikasi Teknologi Informasi.

[4] Fauzan, M., \& Fiqiana, P. (2016). Aplikasi Rumah Pintar (Smart Home) Pengendali Peralatan Elektronik Rumah Tangga Berbasis Web. Jurnal Teknologi Informasi dan Ilmu Komputer.

[5] Irma, N. N. (2015). Rancangan Bangun Web User Interface Untuk Smart Home Monitoring Menggunakan Icomsat.

[6] Latifah, I. (2017). Sistem Smart Home Untuk Kendali Piranti Elektronik Rumah Tangga Berbasis Web. Yogyakarta: Tugas Akhir Diploma Teknik Elektro UGM.

[7] Lhaksmana, K. M., \& Murdiansyah, D. T. (2018). Aplikasi Internet of Things Untuk Pengendali dan Pemantau Kendaraan. Eproceeding of Engineering, pp.

[8] Made, C. S., \& Rendy, M. (2013). Performance Analysis and Design Of Wireless Sensor Network In Smart Home.

[9] Mikrotik ID : produk Detail: Router Wireless RB951-2n [WWW Document]. (n.d.). Retrieved Februari 15, 2019, from http://www.mikrotik.co.id/produk_lihat.php?id=320

[10] PHP - Pengertian PHP - Fungsi, Syntax, dan Alasan Menggunakan PHP [WWW Document]. (n.d.). Retrieved Desember 2, 2020, from https://www.jagoanhosting.com/blog/pengertian-php/

[11] Rahmasari, F. (2016). Sistem Kendali Smart Room Dengan Menggunakan Sensor Voice Recognition Berbasis Android. Yogyakarta: Tugas Akhir Diploma Teknik Elektro UGM.

[12] RESLAB - Mengenal MQTT Protokol untuk IOT [WWW Document]. (n.d.). Retrieved Desember 12, 2020, from http://reslab.sk.fti.unand.ac.id/index.php?option=com_k2\&review =item\&id=229:mengenal-mqtt-protokol-untuk-iot\&Itemid=303

[13] Sukmahati, K. (2018). Pengamatan Parameter Jaringan Pada Kendali Nyala Lampu LED Berbasis Arduino. Yogyakarta: Proyek Akhir Sarjana terapan Teknologi Rekayasa Internet UGM.

[14] Widya, A. (2016). Kontrol Rela Menggunakan Wi-Fi Melalui Ponsel Pintar Android. Yogyakarta: Tugas Akhir Diploma Elektro UGM.

\section{KESIMPULAN}

Berdasarkan hasil dan analisis dari perancangan dan penggunaan pengujian blackbox terhadap prototipe sistem kontrol lampu LED berbasis arduino dan website, dapat disimpulkan bahwa Blackbox testing untuk perangkat lunak menghasilkan 21 status berhasil dan 0 gagal. Sementara hasil pengujian perangkat keras adalah 5 status berhasil dan 0 gagal. Hasil blackbox testing pada sistem 